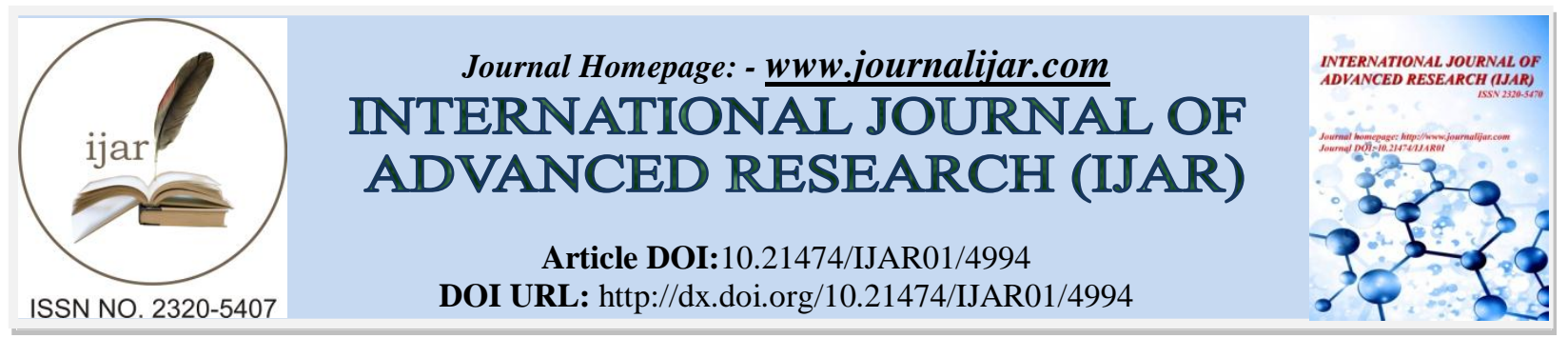

RESEARCH ARTICLE

\title{
A STUDY ON GENDER DISPARITY IN NUTRITIONAL STATUS AMONG SCHOOL GOING CHILDREN IN A RURAL COMMUNITY OF ALLAHABAD, UTTAR PRADESH, INDIA.
}

\section{Jaya Tripathi ${ }^{1}$, Ranu Prasad ${ }^{2}$, Alka Gupta ${ }^{3}$ and Anisha Verma ${ }^{3}$.}

1. Senior Research Fellow, Ethelind College of Home Science, Sam Higginbottom University of Agriculture, Technology and Sciences, Allahabad.

2. Dean, Ethelind College of Home Science, Sam Higginbottom University of Agriculture, Technology and Sciences, Allahabad.

3. Assistant Professor, Ethelind College of Home Science, Sam Higginbottom University of Agriculture, Technology and Sciences, Allahabad.

\section{Manuscript Info}

Manuscript History

Received: 28 May 2017

Final Accepted: 30 June 2017

Published: July 2017

Key words:-

Nutritional Status; Gender Disparity;

Underweight; Illness; Malnourishment

\section{Abstract}

Though the importance of girl child has been stressed time and again, yet a wide level of disparity still exists, whether implicit or explicit, in nutrition and child care both in the rural and urban areas. Different underlying factors are responsible for this disparity. Girls face discrimination from the moment she is born. The UNICEF intergenerational cycle of malnutrition stresses on the fact that the problem of malnutrition spans generation and is a vicious cycle. Therefore this study is conducted to document the gender disparity in nutritional status with the objectives to compare the gender disparity in nutritional status in children aged 7-12 years in rural areas and to assess the different socio-demographic factors influencing the gender disparity. A community based cross-sectional study was conducted in Allahabad area of Uttar Pradesh. A total of 161 children were examined and their mother's were interviewed. Male children were more malnourished than female children. Although the frequency of falling ill is the same between both the genders, the treatment was given more importance to male than female children. The overall prevalence of disease was low in our study area. The majority of the children suffered with fever, diarrhoea, and acute respiratory infection. Significant differentiation was observed between the male and female children with regard to the time lag between child falling ill and initiation of treatment and the amount spent for treatment. Male children were more malnourished than female children. This is contrary to the general belief that female children are more malnourished.

Copy Right, IJAR, 2017,. All rights reserved.

\section{Introduction:-}

Under nutrition is a serious public health problem among children in the developing countries (Nandy, et. al 2005). Under nutrition is one of the measures of health status that the World Health Organization (WHO) recommends for equity in health (Zere and McIntyre 2003). It has been estimated this approximately $70 \%$ of the world's 
undernourished children live in Asia, giving that region the highest concentration of worldwide childhood under nutrition (Khor, 2008). Moreover, India shows the highest occurrence of childhood under nutrition in the world and it has been estimated that more than half of Indian children are undernourished (Bamji, 2003). Malnutrition impedes motor, sensory, cognitive and social development, so malnourished children will be less likely to benefit from schooling, and will consequently have lower income as adults. The most damaging effects of under-nutrition occur during pregnancy and the first two years of a child's life these damages are irreversible. It is the right of every child to know and be cared for by his/her parents. The responsibilities for the child's well-being rely on both the parents and the society. Since the ancient times, it is the gender that determines the position of a child in the Indian society. Denial of equality, rights, opportunity and supplement in any form on the basis of gender is gender discrimination. Gender discrimination is meant for women, because the female subjects are more often the victims. The girl child faces the neglect of the family in the form of a failure to provide her the basic necessities of life in terms of food, clothing, love, shelter, supervision, education, and medical care. Gender inequality exists in every country, but it varies in degree. A major area of concern and focus in India is the remarkable degree of variation in demographic profile, socioeconomic factors, and cultural practices.

\section{Scope:-}

Discriminations, whether implicit or explicit, in nutrition and child care have exacerbated the plight of the girl child, which manifests in excess female mortality, as has been highlighted by many studies. Girl child are biologically advantageous than the male child in the perinatal and neonatal period. But this advantage is overridden by the societal practices and discrimination as the child grows. Girls face discrimination from the moment she is born. And this discrimination manifests itself in every walk of life. In other words, they are not reared as equivalent to their male counterpart. Though the importance of girl child has been stressed time and again, yet a wide level of disparity still exists both in the rural areas. Different underlying factors are responsible for this disparity in the rural areas. Achieving gender equity is one of the main cornerstones for achieving universal health coverage. Therefore this study is conducted to document the gender disparity in nutritional status and compare rural and urban differences.

\section{Aims \& Objectives:-}

1. To compare the gender disparity in nutritional status in children aged 7-12 years.

2. To assess the different socio-demographic factors influencing the gender disparity.

\section{Research Methodology:-}

Study Design: Community based cross-sectional study.

Study Area: The present study has been carried out in Jasra block of Allahabad district.

Study Population: Children in the age group of 7-12 years.

Inclusion Criteria: Children in the age group of 7-12 years.

Exclusion Criteria: Children diagnosed with serious medical condition.

Sample Size: 161 children were selected using purposive random sampling.

Data Collection Tools: Pre-designed and pre-tested schedule, weighing scale and measuring tape.

Data Collection Technique: House to house visit, examination and interview method.

\section{Methods of measurements:-}

Height: Height was measured using a measuring tape. The participants were asked to remove their footwear (shoes, slippers, sandals, etc.) and head gear (hair bows, ribbons etc.), the participants were told to stand with feet together, heels against the wall, knees straight, to look straight ahead and not tilt their head up. It was made sure eyes were the same level as the ears (Frankfurt plane). A cardboard was gradually brought down and the measurement was read to the nearest $0.1 \mathrm{~cm}$.

\section{Weight:-}

Weight was taken with the help of a bathroom scale (Putex - 00002) to the nearest of $0.5 \mathrm{~kg}$ reading. The scale was adjusted to zero. The scale used was easily portable, sturdy, inexpensive and light to be carried for the community research. To ensure the accuracy, it was checked from time to time. The respondents were weighed before mid day meal in school uniforms only.

The WHO Growth Charts (2006) were used to classify the children as normal, mild to moderate and severe type of malnutrition. 


\section{Findings:-}

Results as shown in table 1 revealed that out of the 161 under-five children, $72(44.7 \%)$ children were classified as underweight for their respective age. Around $40 \%$ of male children were classified as mild to moderately underweight when compared with $23.5 \%$ of female children. However, a higher percentage of female children $(17.3 \%)$ were severely underweight than male children $(8.8 \%)$. The association was also found to be statistically significant. Stunting was seen more in the female children (30.9\% vs. $17.5 \%)$ than male children. The association was found to be statistically non-significant. On measuring the weight for height of the under-five children using the WHO Growth Charts, male children were found to be wasted than the female children. But, the association was found to be statistically non-significant.

The majority of the children were of age of 8 years, with the majority (78.3\%) belonging to the Hindu by religion. Equal number of boys and girls were present in the study. About $72.2 \%$ of the children belonged to joint family. Overall, $44.7 \%$ of the children were underweight, $39.7 \%$ were stunted, and $30.3 \%$ were wasted.

The median height and weight of the majority of children were within the normal range of the WHO reference data. Although, it is believed that male children are better and well-nourished than the female children, the finding in our study is contradictory, which is a positive sign. Similar kinds of results were also seen in the studies done by Ray $\boldsymbol{e t}$ al. (2000), Pathak (2011) and Chakraborty et al. (2006). No such significant difference was observed between both the sexes regarding the prevalence of disease.

Table 1:- Socio-demographic profile of the children.

\begin{tabular}{|c|c|c|}
\hline & $\mathbf{N}$ & $\%$ \\
\hline \multicolumn{3}{|l|}{ Age group (in years) } \\
\hline 7 years & 17 & 10.6 \\
\hline 8 years & 43 & 26.7 \\
\hline 9 years & 40 & 24.8 \\
\hline 10 years & 37 & 23 \\
\hline 11 years & 20 & 12.42 \\
\hline 12 years & 4 & 2.4 \\
\hline \multicolumn{3}{|l|}{ Religion } \\
\hline Hindu & 126 & 78.3 \\
\hline Other religions & 35 & 21.7 \\
\hline \multicolumn{3}{|l|}{ Gender } \\
\hline Male & 80 & 49.7 \\
\hline Female & 81 & 50.3 \\
\hline \multicolumn{3}{|l|}{ Type of family } \\
\hline Nuclear & 45 & 27.8 \\
\hline Joint & 116 & 72.2 \\
\hline \multicolumn{3}{|l|}{ Socio-economic Status } \\
\hline ( & 11 & 6.8 \\
\hline 2 & 23 & 14.3 \\
\hline 3 & 48 & 29.8 \\
\hline 4 & 61 & 37.9 \\
\hline 5 & 18 & 11.2 \\
\hline
\end{tabular}

Table 2:- Distribution of children based on weight for age.

\begin{tabular}{|l|c|c|c|}
\hline \multicolumn{1}{|c|}{ Weight for age } & $\begin{array}{c}\text { Male subjects, } \boldsymbol{N} \\
(\boldsymbol{\%})\end{array}$ & $\begin{array}{c}\text { Female subjects } \boldsymbol{N} \\
(\boldsymbol{\%})\end{array}$ & Total \\
\hline Normal ( +2 SD to -2 SD) & $41(51.2)$ & $48(59.3)$ & $89(55.3)$ \\
\hline Underweight & $32(40)$ & $19(23.5)$ & $51(31.7)$ \\
\hline Mild to moderate (-2 SD to -3 SD) & $7(8.8)$ & $14(17.3)$ & $21(13)$ \\
\hline Severe (less than -3 SD) & & \multicolumn{3}{|l|}{} \\
\hline
\end{tabular}


Table 3:- Distribution of children based on height for age.

\begin{tabular}{|c|c|c|c|}
\hline Height for age & $\begin{array}{c}\text { Male subjects, } N \\
(\%)\end{array}$ & $\begin{array}{c}\text { Female subjects, } N \\
(\%)\end{array}$ & Total \\
\hline Normal (+2 SD to $-2 \mathrm{SD})$ & $52(65)$ & $45(55.5)$ & $97(60.2)$ \\
\hline \multicolumn{4}{|l|}{ Stunting } \\
\hline Mild to moderate ( -2 SD to $-3 \mathrm{SD})$ & 14 (17.5) & $25(30.9)$ & $39(24.2)$ \\
\hline Severe (less than -3 SD) & $14(17.5)$ & $11(13.6)$ & $25(15.5)$ \\
\hline
\end{tabular}

Table 4:- Distribution of children based on weight for height.

\begin{tabular}{|l|c|c|c|}
\hline & \multicolumn{2}{|c|}{ Gender } & Total \\
\hline Weight for height & $\begin{array}{c}\text { Male subjects, } \boldsymbol{N} \\
(\mathbf{\%})\end{array}$ & $\begin{array}{l}\text { Female subjects, } \boldsymbol{N} \\
(\mathbf{\%})\end{array}$ & \\
\hline Normal (+2 SD to -2 SD) & $36(60)$ & $49(79)$ & $85(69.7)$ \\
\hline Wasting & $17(31.7)$ & $14(19.4)$ & $31(25.4)$ \\
\hline Mild to moderate (-2 SD to -3 SD) & $5(8.3)$ & $1(1.6)$ & $6(4.9)$ \\
\hline Severe (less than -3 SD)
\end{tabular}

The possibilities of the recall bias do exist in our study. Unfortunately, we could contact very few fathers during our visit, as most of them were sole bread earners of the family and had left for the work early in the morning. Hence, information on knowledge, attitude, and practice regarding child-rearing practices and care during illness has not been analyzed completely. Nutritional status is a major determinant of health and well-being in children. This is similar to other studies done in different parts of India by various researchers like Dey and Chaudhuri (2008), Bhalani and Kotecha (2002) and Dasgupta (1987). However, in rural areas, the male child had higher rates of underweight and stunting as compared to the female child. This is similar to other studies as reported by Singh and Mondal (2013), and Basu et. al (2014).

\section{Conclusion:-}

Male children were more malnourished than female children. This is contrary to the general belief that female children are more malnourished. There was a significant association between underweight and gender in Hindu religion, caste, nuclear family, illiterate and unemployed mother and lower income group. Gender equity is an important determinant to curb the menace of under nutrition. Though the problem of gender disparity is not as prevalent in Assam as other part of India yet its existence can't be totally ignored. Different underlying factors play their part in the manifestation of gender discrimination. Until and unless steps are taken to deal with the social determinants of under nutrition its burden can't be lessened.

\section{Recommendations:-}

1. Percolating the message of gender equality deep into the community through IEC and empowerment of females in the society.

2. Special focus on creating awareness on gender equality in the minority communities and backward castes.

3. Intense awareness generation through mass media approach, stressing on female literacy, improving the overall socioeconomic conditions through various income generation schemes.

\section{References:-}

1. Nandy, S., Irving, M., Gordon, D., Subramanian, S.V. \& Smith, G.D. (2005). Poverty, Child Under nutrition and Morbidity: New Evidences from India. Bulletin of World Health Organization, 83, 210-216.

2. Zere, E. \& McIntyre, D. (2003). Inequities in under-five child malnutrition in South Africa. International Journal of Equity Health, $2,7$.

3. Khor, G.L. (2008). Food-based approaches to combat the double burden among the poor: Challenges in the Asian context. Asia Pacific Journal of Clinical Nutrition, 17, 111-115.

4. Bamji, M.S. (2003). Early nutrition and health - Indian perspective. Current Science, 85(11), 37-42.

5. Ray, S.K., Biswas, A.B., Gupta, S.D., Mukherjee, D., Kumar, S. \& Biswas, B. (2000). Rapid assessment of nutritional status and dietary pattern in municipal area. Indian Journal of Community Medicine, 25(1), 14-18.

6. Pathak, D. (2011). Gender Disparity in Health and Nutritional Status in Children under Five Years of Age in a Rural Community: A Cross-Sectional Study. MPH Thesis, Belgaum, KLE University. 
7. Chakraborty, S., Gupta, S.B., Chaturvedi, B. \& Chakraborty, S.K. (2006). A study on protein energy malnutrition (PEM) in children (0-6 years) in a rural population of Jhansi district (UP). Indian Journal of Community Medicine, 31(4), 291-292.

8. Census provisional population totals. (2011). Available from: http://censusindia.gov.in/2011census/censusinfodashboard/index.html

9. National Family Health Survey (NFHS-3). (2007). International Institute for Population Sciences (IIPS) and Macro International.

10. Dey, I., Chaudhuri, R.N. (2008). Gender Inequality in Nutritional Status among under Five Children in a Village in Hooghly District, West Bengal. Indian Journal of Public Health, 52(4), 218-220.

11. Bhalani, K.D. \& Kotecha, P.V. (2002). Nutritional status and gender differences in children of age less than five years of age attending ICDS anganwadis in Vadodara city. Indian Journal of Community Medicine, 27(3): 124129.

12. Gupta, M.D. (1987). Selective Discrimination against Female Children in Rural Punjab, India. Population and Development Review, 13, 77-100.

13. Mosley, W.H. \& Chen, L.C. (1984). An analytical framework for the study of child survival in developing countries. Population and development review (Suppl.), 10, 25-45.

14. Singh, J. \& Mondal, N. (2013). Assessment of Nutritional Status: A Case of Tribal Children in Assam, Northeast India. Journal of Nepal Paediatrics Society, 33(1), 1-7.

15. Debashis, B., Gulenur, I., Ratul, G., Swarupa, D. \& Junumai D. (2014). Childs growth and nutritional status in two communities-Mishing tribe and Kaibarta caste of Assam, India. International Journal of Sociology and Anthropology, 6(2):59-69.

16. United Nations Development Programmes. Gender Inequality Index and Related Indicators. 2011.

17. World Health Organization. Growth Charts (2006). Available at: http://www.who.int/childgrowth/standards/en/. 